\title{
LX. Account of a new spring of petroleum discovered in Italy; in a letter to the editors of the annales de chimie
}

\section{J. Poggi}

To cite this article: J. Poggi (1803) LX. Account of a new spring of petroleum discovered in Italy; in a letter to the editors of the annales de chimie , Philosophical Magazine Series 1, 16:64, 321-324, DOI: $10.1080 / 14786440308676354$

To link to this article: http://dx.doi.org/10.1080/14786440308676354

曲 Published online: 18 May 2009.

Submit your article to this journal $\pi$

Џll Article views: 2

Q View related articles $\sqsubset$ 
we saw them produce young ones at Rome the preceding year, and as that produced in 1801 is lively, and now in the possession of the princess Venosa."

The witnesses who attest the above are :

Dr. Louis Bernardi,

Joseph Taruchi, surgeon,

Felix Alberici, canon,

Bernard Piermattei.

It is to be regretted that the hatching of these parrots has not been attended with the same success as it was last year.

We here see that the climate of Orvieto, which is more temperate than that of Rome, was no obstacle to the copulation or laying of these birds. What in all probability prevented the female from hatching the eggs was, that the parrots were not in separate apartments as the preceding year, and that they were deranged by the too great number of people who approached them either through curiosity or by accident, since they were placed in a chamber which served as a kitchen.

These birds are suspicious and timid, and it is probable that the female bruised the eggs in endeavouring to change their position with a view of placing them in more safety.

But as these birds, according to my calculation, are in the vigour of youth, it is to be hoped they will produce young hereafter; and that the owner, taught by the experience of this year, will take the necessary precaution of placing them in an apartment less exposed to noise and bustle, where the solitude of the place may bring them nearer to the wild state, and suffer them to complete their incubation as during the preceding year.

Turin,

September 25,1802 .

LX. Account of a new Spring of Petroleum discovered in Italy; in a Letter to the Editors of the Annales de Chimie. By J. Pogri *.

$\mathrm{B}_{\mathrm{EING}}$ detained in the capital by the great means it affords of applying to the study of nature, I think it my duty to communicate to you an account of an interesting phrnomenon with which nature has enriched my country. It consists in a very abundant and permanent spring of petroleum or naptha, which has appeared for some months at

VoL. XVI. No. 64.

* From the Annales de Cbimie, No. 134. 
Amiano, a village in the state of Parma, near Josnovo and Varese, on the confines of Liguria. Being vexed that the government of the country did not take this object into consideration, I have heard lately with satisfaction that the government of Liguria has converted it to a useful purpose. After being analysed by an able chemist, it has been applied with great advantage to the purpose of lighting the city of Gepoa.

It was C. Mojon, professor of chemistry in the umiversity of Genoa, who made the most conclusive experiments on this combustible substance. He read a report on this subject before the National Institiste of Liguria on the 4 th of July 1802 ; and it is an extract from this report, procured from the autkor himself, that I now have the honour of presenting to you.

Professor Mojon, having been on the spot, was enabled to see that the richness of the spring of petroleum at Amiano is so great, that; though people have continually drawn from it since its discovery, it still keeps at the same level. He has found in it the following characters :

This petroleum is exceedingly limpid, of a vinous yellow colour, or rather like that of the topase of Saxony. I1s smell is strong, penetrating, and less empyreumatic than that of the common and brownish petroleum. Its specific gravity is to that of water as 83 to 100, and to that of olive oil as 91 to 100.

If a few drops of it be poured on writing paper and exposed to heat, it is entirely volatilised, and leaves no stain. If distilled in a glass retort, in a moderate heat, it passes entirely into the receiver, and leaves no residuum.

If it be mixed with concentrated sulphuric acid, it burns, becomes thick and dark-coloured. It readily dissolves amber, sulphur, and resins; and when mixed with gum copal forms a varnish, which, when spread over a piece of board, and exposed for some days to the sun, dries, and loses its odour. When poured on alcohol, it floats at the surface without dissolving, even when heated and strengly stirred. It floats also over fixed and volatile oils, with which it combines by agitation. Its combustibility is so great, that it inffames when brought near to a burning body : it seems even to attract the flame in consequence of its great volatility. Its own flame is white and lively, like that of oil of turpentine, but it emits much more smoke.

Having thus determined the characters of petroleun, professor Mojon, mindful of his commission, examined whether it anight not be employed for lighting the city of Ge- 
noa. He made experiments to ascertain the intensity and degree of the light which this liquid produces in comparison of olive oil ; and was able to make an exact calculation how far it would be advantageous to cmploy it.

He put an ounce of petroleum into a glass lamp; added a flat wick of four lines in breadth, placing it in such a manner that the bottom of the flame should be about an inch above the fluid. He then put an ounce of olive oil into another lamp of the same kind, and kindled both lamps at the same time. They gave a flame equally strong, and a light of the same intensity; but with this difference, that the former alone produced a little smoke, and burnt an hour and a half, while the lamp containing the olive oil burnt an hour and thirty-five minutes. Both of them were then dry, without leaving any residuum.

In order to try whether the smoke might not be destroyed or diminished, he burnt the petroleum in a lamp with a current of air furnished with a glass cylinder. He indeed found that the liquid, while it burned completely with a white and very bright flame, emitted no longer any smoke or bad smell. The combustion was so rapid that the flame was agitated by it. Having then introduced into the same lamp a mixture of equal parts of petroleum and olive oil, he obtained a slower combustion, with a more tranquil and uniform flame. He obtained the same result by the union of these two substances in a reverberating lamp with a wick of about an inch in breadth.

From these experiments he concluded that this petroleum might be advantageously employed for lighting the streets, observing the following precautions : oil.

1st, That the flame should be about an inch above the

2d, That the lamp should be covered and closed in such a manner as to prevent the flame from being communicated to the petroleum.

$3 d$, To use a flat wick, to prevent smoke and render the combustion complete.

It was in consequence of this report of professor Mojon that the Ligurian government ordered petroleum to be employed for lighting the streets of Genoa. It is used at present without any mixture: the reverberators are constructed with the improvements above indicated; but care has been taken to adr a kind of conical tube or chimney of tin plate, to convey off the smoke which may be disengaged. By these means the same quantity of light is obtained as with $\mathrm{X} 2$ 
olive oil, and at a fourth of the expense, as the petroleum costs only two Genoese sous per pound, (which is less than a penny English.)

LXI. Report on the Discovery of a Deposit of lituminous Wood. Read in the Ligurian Institute July 1802 by C. Moson, pullic Professor of Chemistry *

$A_{T}$ the period when nature opened in the state of Parma, on the north side of the Appenines, an extraordinary spring of petroleum $\uparrow$, it presented on the opposite side, in Liguria, at the distance of about fitteen leagues, a considerable depôt of bituminous wood. The discovery of this fossil is even a little more recent, and is equally interesting to the naturalist and to the state. For a knowledge of it we are indebted to the useful labours of professor Mojon, as will be seen by the following extract from the report which he made to the National Institute of Liguria:

"Castel Nuovo is a country of Lunigiana on the confines of the Italian republic. It is in the plain of that country, half a league from the mouth of the Magra, that the mine of the substance in question has been discovered. It is situated in a soil formed of argillaceous and calcareous strata, more or less thick, and inclined in different directions throughout their whole extent. The nature of the fossil, as well as the constitution of the soil, evidently shows that these strata were formed only by great floods, which carried with them and buried whole forests $f$. The extent of this deposit, however, cannot be determined, because the pits proposed to be sunk at different distances for that purpose have not yet been constructed. Hitherto one only has been made, about 40 feet in depth, the bottom of which is inundated by a spring that issues from an excavation attempted in a lateral direction; and it is to be observed, that in this pit no disengagement has been remarked of carbonic acid gai, nor of those gases generally developed from such excavations.

* From the Annales de Chimie, No. 135.

+ See the preceding article.

IIs there not reasrin to believe that the lucus sacer of the antient Lun must form part of this deposit? The ruins of the towll, in digging among which monuments worthy the attention of the antiquary have lately been discovered, are found very near, and at the distance of the third of a league from the mouth of the Magra. 